\title{
Construction of photo-rechargeable battery using rhodamine B
}

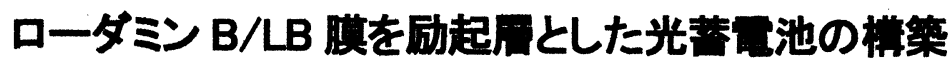

\author{
Hiroki WATANABE and Sadao UEGUSA
}

Department of Electrical Engineering, Tokai University, 1117 Kitakaname, Hiratsuka, Kanagawa, 259-1292, JAPAN

TEL : $+81-463-58-1211$ (EXT. 4162)

\section{Kenichiro NAKANURA}

Department of Optical Engineering, Tokai University, 1117 Kitakaname, Hiratsuka, Kanagawa, 259-1292, JAPAN

TEL : $+81-463-58-1211$ (EXT. 4423)

(Received 19, November 2001 Accepted 26, July 2002)

Photo-rechargeable battery was constituted using the Pori-Pyrrole and Rhodaminine B as a photocatalyst layer and an electronic accumulation material respectively. Accumulation voltage and efficiency were measured with different polymerization voltage of $0.5 \sim 3.0[\mathrm{~V}]$. At lower polymerization voltage, higher photo-voltaic efficiency was obtained.

KEYWORDS : photo-rechargeable battery, efficiency measurement, thodamine B dye mixed LB film

\section{INTRODUCTION}

近年、化石然料の枯渴と公害問題が深刻化している一 方で、これからのクリーンエネルギーとして太陽エネル ギーが注目されている。本研究は、太陽光を利用したデ バイスである光蓄電池の素子の簡易化、蓄電性能の向上 を目的としている。感光色素として知られているローダ ミン B(RhodamineB NKX-736 : RB) 色素を LB (Langmuir Blodgett) 法を用いて製膜すると、光電変換の機能を有す

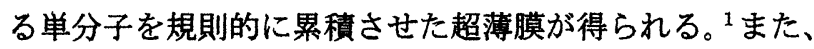
ピロールを電解重合法により重合させると、導電性高分 子であるポリピロール膜が得られる。

本研究では、RB 色素 LB 膜を光触媒として用いた。こ れを、蓄電材料であるポリピロール膜面上に超薄膜とし て形成し、光電変換と蓄電を同一素子で行う光蓄電池を 作製した。 ${ }^{2}$ また、定電位電解重合における、重合電圧の 値をパラメータとした光蓄電池の充電電圧、効率を測定 した。これより、重合電圧について光蓄電池の性能が最 大となるポリピロール膜作製重合電圧条件を検討した。

\section{EXPERIMENTAL}

II -A. The accumulation of electricity character $i$ stic by polymerization voltage change

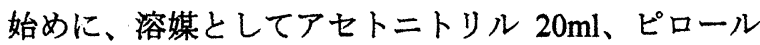
$3.0 \mathrm{ml}$ を用いた。支持電解質として無水ホウフッ化リチ
ウム $30 \mathrm{mg}$ 、膜強化のためポリビニルアルコール $20 \mathrm{mg}$ を 混入し、十分筧拌した。その後、真空引きを行い、これ を電解重合溶液とした。電極は、主電極にネサガラス, 対向電極に白金を用い、両電極を $2.5 \mathrm{~cm}$ の間隔で溶液中 に $1 \mathrm{~cm}^{2}$ 挿入した。参照電極に $\mathrm{AgCl}$ を用い,Fig. 1 のよ うに配線し定電位で印加することでネサガラス面に $1.5 \mathrm{C}$ 電解重合を行った。重合電荷量はクーロンメータで 設定した。重合電圧はサイクリック・ボルタメトリー (Cyclic Voltammetry) により、0.5〜3.0V の閒で変化 させると共に、酸化開始電位の測定を試みた。

上記の膜上に $\mathrm{RB}$ 色素混合 $\mathrm{LB}$ 膜を累積させた。LB 膜採 取時の表面圧は $30 \mathrm{mN} / \mathrm{cm}$ 、累積数は 5 層に固定し、作製 した膜にレフレックスランプを用いて光照射した。

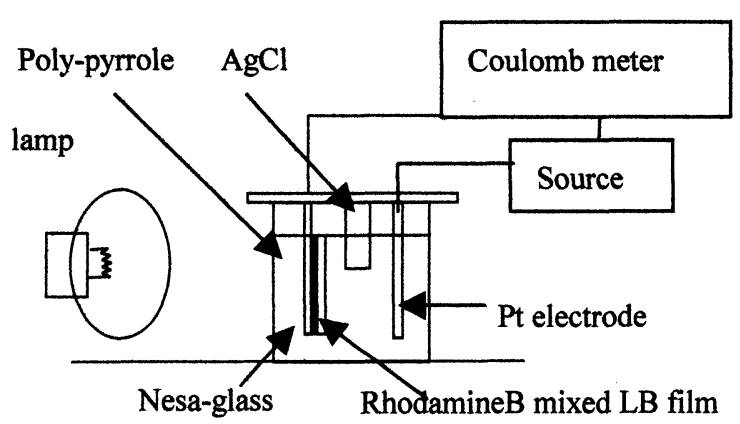

Fig.1. The wiring diagram of experimental apparatus. 
試料面における光出力を $40 \mathrm{~mW}$ に設定して、光照射を 1 分間行い、その後 1 分間光照射を停止した。このサイク ルを 5 回絽り返し、蓄電電圧值の変化を測定した。

\section{II-B. Efficiency measurement}

試料面をレフレックスランプで照射し、試料面におけ る光强度を $30 \mathrm{~mW} / \mathrm{c} \mathrm{m}^{2}$ に設定した。電解質は、アセ卜 ニトリル、ホウフッカリチウムを用い、抵抗值を 0 ～100 $\Omega$ まで変化させた場合の電圧値、電流値を求め以下の (1) 式で効率 $\eta$ を算出した。

$$
\begin{aligned}
& \eta=100 \cdot \mathrm{I} \mathrm{pm}(\mathrm{mA}) \cdot \mathrm{V} \mathrm{pm}(\mathrm{mV}) / \mathrm{S} \cdot \mathrm{I}(\%) \cdot(1) \\
& \mathrm{I}: \text { 照射強度 }\left(\mathrm{mW} / \mathrm{cm}^{2}\right) \quad \mathrm{S} \text { :秦子面䅡 }\left(\mathrm{c} \mathrm{m}^{2}\right)
\end{aligned}
$$

\section{RESULTS AND DISCUSSION}

Figure2 にサイクリック・ボルタメトリーの測定結果 を示す。その結果から、酸化電位、すなわちピロールの 重合開始電位が $0.5 \mathrm{~V}$ にあることが明らかである。従っ て、本実験における安定したピロール膜の重合開始電圧 は、 $0.5 \mathrm{~V}$ 以上である。また、重合電圧 $3.5 \mathrm{~V}$ 以上では、 溶液中の窒素が化学反応を生じたため測定を中止した。

以上の結果から重合電圧を $0.5 、 1.0 、 2.0 、 3.0(\mathrm{~V})$ と変化させた場合の 10 分間光光照射一蓄電特性を得た。 これをFig3に示す。同図では、重合電圧が低いほど開放 電圧值が高くなることが明らかである。また、充電電圧 は、蓄放電電圧の差から、開放電圧の値と同様、重合電 圧値の低い場合が、高い値を示している。また、充電電 圧と開放電圧の値は、共に重合電圧の低い場合が高い值 を示している。

Figure4 に各重合電圧で製作した試料に対する効率特 性を示す。同図から、重合電圧の值が高くなるほど効率 は低くなる傾向にある。しかし、その変化量は極めて低 く、約 $1 \%$ 以内の変化でしかない。また、各重合電圧に おける最高効率は、それぞれ負荷が $50 \mathrm{k} \Omega \sim 60 \mathrm{k} \Omega$ の場 合に表れた。これは素子の内部抵抗がかなり高いことを 表しており、電極の間隔を小さくするなどの改善を要す る。

以上の実験結果より、重合電圧を低く設定することに より、重合時間が長いほど、すなわち構造規則性の高い 重合膜が得られると考えられる。すなわち禁制帯中の卜 ラップレベルの数が減少し、充電電位が上昇しやすくな る。ゆえに、光蓄電池としての性能が向上したと考えら れる。

\section{CONCLUSION}

i ）ローダミン B L B 膜を光励起層とした場合、光蓄電 池として動作することを確認した。

ii）重合電圧を低く設定し重合を行った場合、重合時間 が長くなり、これにより、規則性の高い重合膜が得 られる。これが開放電圧・重合電圧が高くなった理 由であると考えられる。

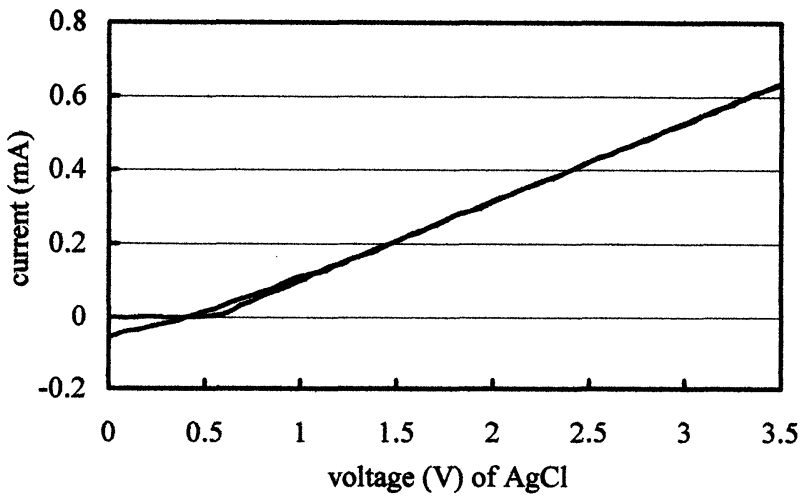

Fig. 2. Voltage change of Cyclic Voltammetry .

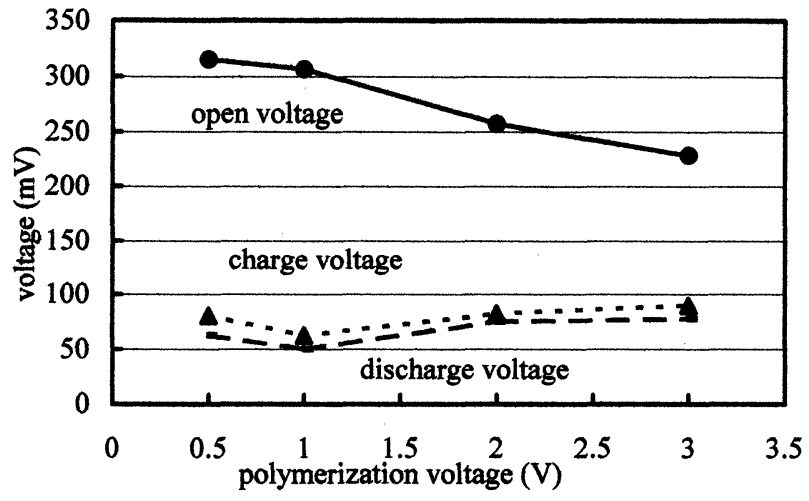

Fig. 3. Optical irradiation-accumulation characteristics .

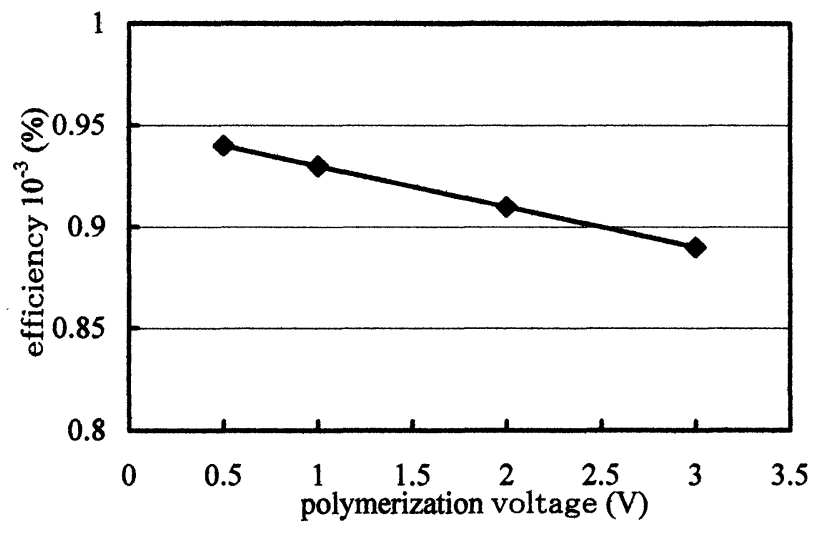

Fig. 4. Accumulation efficiency .

iii）変換効率の場合も同様、重合電圧を低く設定したほ うが高い值を示した。

\section{REFERENCES}

${ }^{1} \mathrm{~K}$.Yosino, The foundation of a conductive polymer, and appli cation,Tokyo,(1988)

${ }^{2}$ S.Uegusa,Myrocyanine mixed LB film photo-rechargeable battery by current controlled polymerization method, Industry science laboratory research report,(1999)

Presented at '01 SAS Intelligent Symposium 